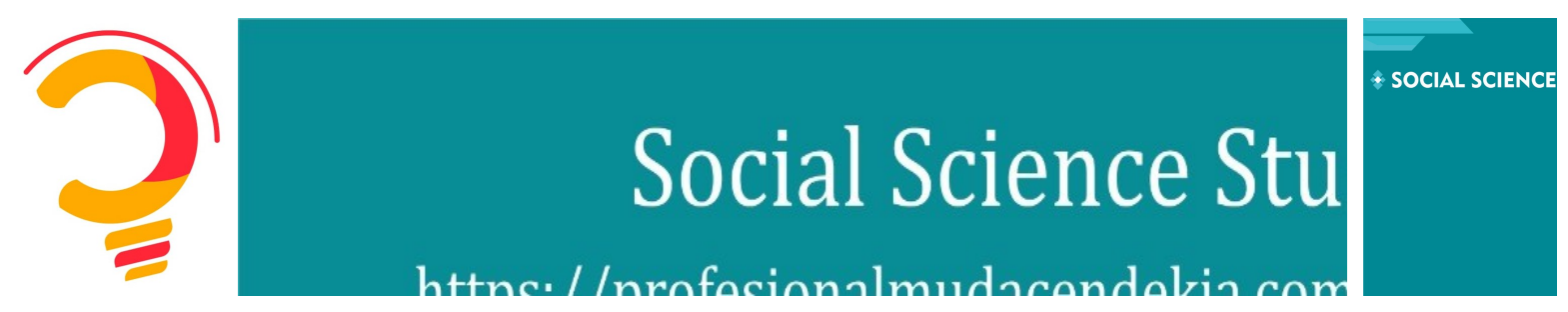

\title{
Attachment Theory: How Marvelous Mother Guided An Adoption Child
}

Eka Mareta Suharyanti1 ${ }^{*}$,

Duwi Handayani,

Adi Manggala Saputro,

Abdillah Nugroho

1,2,3,4. Magister Pendidikan Bahasa Inggris, Universitas Muhammadiyah Surakarta,Indonesia.

\begin{tabular}{ll}
\hline ARTICLE INFO & ABSTRACT \\
\hline ISSN: 0101-0721 & $\begin{array}{l}\text { The paper focuses on analyzing a mother who guides an adoption child reflected } \\
\text { in The Blind Side movie. The researcher applies descriptive qualitative method in } \\
\text { analysing the problem to find the data. The research questions are 1. What } \\
\text { problems are faced by Leigh Anne's, as a mother? 2. What are the factors cause } \\
\text { those problems? 3. How does Leigh Anne's solve the problems? The first data }\end{array}$ \\
Keywords: & $\begin{array}{l}\text { Adoption, Guiding } \\
\text { children, attachment } \\
\text { theory. }\end{array}$ \\
children and the second data that support the analysis. The technique of the data \\
attachment theory by John Bowlby. The result shows that Leigh Anne Tuohy \\
creates efforts in her supporting strategy such as adopted Oher to be her family, \\
Mrs. Tuohy's guide Oher to be an American football player. Part of that \\
emotional funding for Leigh Anne is that finaly Oher can find his potential as a \\
human being and find his identity to be a happy person like everyone else.The \\
result is the power of love a marvelous mother can make Oher to be a successful \\
American football player.
\end{tabular}

\section{Introduction}

What had happened and became a trend in the US. Most of the people adoption of children from Afrika. The pop star Madonna wanted to adopt a child from Malawi for the second time. She has adopted a boy from Malawi, David Banda (4) in 2016. Then Madonna wanted to adopt Chifundo"Mercy" James, she is a girl (4) years.

Madonna was not the only one who adopt the children from other countries, according to data from US Department of State, US Citizens have adopted 1.725 children from Ethiopia in the period September 2007 - September 2008. That number increased from the previous period that is 1.255 Ethiopian children. About 70 percent of African adopted by US citizens are from Ethiopia.

Social Science Studies Vol. 1 No. 12021 Page 032-044

DOI: $10.47153 /$ sss11.1782021

*Corresponding Author

Email address: s400190010@student.ums.ac.id 
The good side of adoption by Madonna and the other people just like actresses or actors it attracted the attention many people possibly in the world. Adoption changed some of the children got family, parents, education, and the main point is their happiness. Many children do not have parents, or they are maybe poor. They need to continue their life, being happy just like other people. Sometimes the poor people in Indonesia will ask their children to be beggars, collecting money to buy rice or food. The other story the children who did not have parents will not have their education, they will be criminals. Nobody gives them a suggestion to be good children, cause they usually gather in a bad environment("Madonna dan Tren Adopsi Anak Afrika," 2009).

The above phenomena are not so far different from those occurring in the movie entitled The Blind Side. The major character, Michael Oher. He is an African American teenager who grew up surrounded by drugs and danger. Then there a beautiful mom, she is Leigh Anne Tuohy adopted Oher to be her son. She has a kind husband named Sean Tuohy who owns lots of fast-food restaurants.

As she started offering him and greater favors, she began to research Oher's records, including his career aptitude test results, where the only positive score was on protective instincts. Leigh Anne will use that to explain to him how to play in the field, up that moment, he wasn't able to get the hang of the game and its rules, and he wasn't to understand what his role on the field was. From that moment, Oher starts to play well and be useful to his team.

Many of Leigh Annas' friends laugh at this project, but she still struggled and in the end she was still able to guide Oher to the right path in life, she got a chance to study at university level, because she got high enough grades, so she had to make a decision. , and he finally did. He chose the university because it was where Sean played and Leigh Anne was the cheerleader. That causes Investigator Granger (Sharon Morris) to tackle the matter before Michael gets there. He questioned her as if they had previously held interrogations at the police station. He thought that Tuohy and Miss Sue used Oher to benefit Ole Nona, their alma mater.

"Haqiqi and Harendika, (2019) explained that equality means that everyone has the same opportunity to compete and achieve success regardless of gender, race, profession, etc. Meanwhile, material wealth can be defined on the social stage as a result of hard work. Finally, Leigh Anne Tuohy and Oher's family struggled to make Michael a successful person".

The paper is aimed at analyzing the phenomenon ofmothersto support an adopted child. Carried out by a mom with a great vision to guide, support, and educate her son through the right track of life. Concerning the aim, a proper theoretical framework to apply is attachment theory. 
The focus of this paper is on guiding theadoption of children with love done by a mother reflected in The Blind Side movie. Based on the focus, it is broken down into some questions as follows; 1 . What problems are faced by Leigh Anne's, as a mother? 2. What are the factors cause those problems? 3. How does Leigh Anne's solve the problems?

Based on the above questions, the purpose of this study is to examine the problems it faces, analyze some of the causes of these problems and examine some of the solutions made by Leigh Anne's. The theoretical significance of this study is to accumulate research on blind side films. We get many perspectives on literary studies from this study, so that it will provide many benefits for readers in understanding the theory of the attachment of mother and adopted child, a means of bringing adopted children into a family by eliminating social and racial disparities and conflicts between families and children.

\section{Literature Review}

According to (Bineham, 2015), he explained that Oher can show that black people can succeed even though the system used is controlled by white people, but seen from the subtext of the message above, it shows that black people cannot succeed alone and will mostly be left behind in conditions of poverty and crime. Perhaps the most debilitating meaning embedded in the persona of Oher's tokenism is that a positive black image entails an ornament of wealth that the existence of an upper or upper middle class is a sign of personal value. This means that everyone will get success.While Oher is nothing without Leigh Anne Tuohy. She is the great mom creating an effort to educate Michael changing his community, environment, and found his ability became an American football player.

Adoption is an activity to take other children from outside family, means that bring and give good life include giving food, clothes, education and everything that children need. Every child in the world has a different life. Maybe they have a mom but they don't have a father. They have a father and mother. They have a father but they don't have a mom. They don't have a father and mother. Also, it can be there is parents don have children. So adoption will give children a good solution. Children need their families to study everything. Then parents need children to make their life complete. And the family will be happy completely. See (Bethmann \& Kvasnicka, 2012)Fertility decisions have been studied extensively by economists, that is, the demand of women and men for own(biological) children. However, children do not have to be sired on self. They can also be adopted.

The family is defined in terms of its function, and the function is the custodial responsibility for children. This will have obvious implications for its form as well: children, for Archard, are a necessary component for a group to be called a family(Cutas \& Smajdor, 2017). 
In an article entitled Attachment Theory: Implications For School Psychology, in this article the author describes a brief overview of attachment theory and explains various risk factors for the development of insecure attachment. The trajectories of children's and adolescent behaviors according to attachment classifications are discussed. Finally, student-teacher interactions in an appendix perspective and implications for the intervention are presented (Kennedy, 2004). According to Brien \& Wiley, (2003) describes the conceptualization of adoption experiences, themes and trends in adoption research related to adoption and biological parents, as well as selected theoretical models of adoption. this can be used as someone to consider variables from the social context to provide an explanation for carrying out the practice of adopting children.

\section{Method}

This method of study is a qualitativedescriptive approach. The object of the study is mother support reflected in the movie. There are two types of the data,the primary data derived from the texts of the movie focusing on Guiding children, attachment theory. The secondary data covers some data that support the analysis. The following steps are the technique of collecting data: to watch the movie, to sort the texts of the movie that relate to mother educate adaption children done by Leigh Anne Tuohy. Applying the attachmenttheory is the technique of the data analysis.

Attachment theory according to (Ainsworth, M. D. S., \& Bowlby, 1991) is Drawing on concepts from ethology, cybernetics, information processing, developmental psychology, and psychoanalysts, John Bowlby formulated the basic tenets of the theory. This study about how mothers closed to the children and how they separate from their family.

\section{Results}

Based on the analysis of the movie, some results can be presented as follows.

1. Leigh Anne Tuohy invites Michael Oher to go home.

The following is her expression of her intention.

Leigh Anne Tuohy: "Turn around”

then her husband turn around the car

Leigh Anne Tuohy:"Stop the car". Then the car stop, while Leigh Anne gets out from the car come to Michael Oher.

Leigh Anne Tuohy: "Hey, my name is Leigh Anne Tuohy.

My kids go to Wingate. You said you're going to the gym? The school gym's closed. Why were you going to the gym? Big Mike?!Why were you going to the gym?"

Michael Oher: "Because... it's warm".

Leigh Anne Tuohy: "Do you have any place to stay tonight? Don't you dare lie to me"? 
Leigh Anne Tuohy: Come on.Come on." While open the car doors and Michael get in the car.

From her question of "Do you have any place to stay tonight?

Don't you dare lie to me!" It can beinterpreted that Leigh Anne knows that Michael Oher doesnot have a place to stay. It means that Leigh Anne must help Oher.

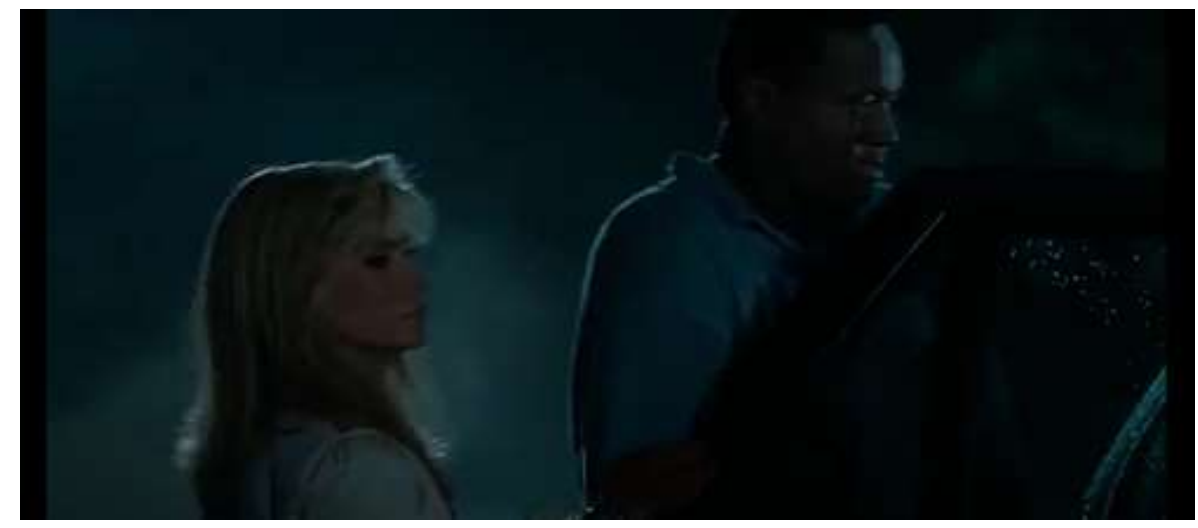

Figure 1: Leigh Anne Tuohy is interested in inviting Michael Oher because he doesn't have a place to stay.

2. Leigh Anne invites Michael to go shopping.

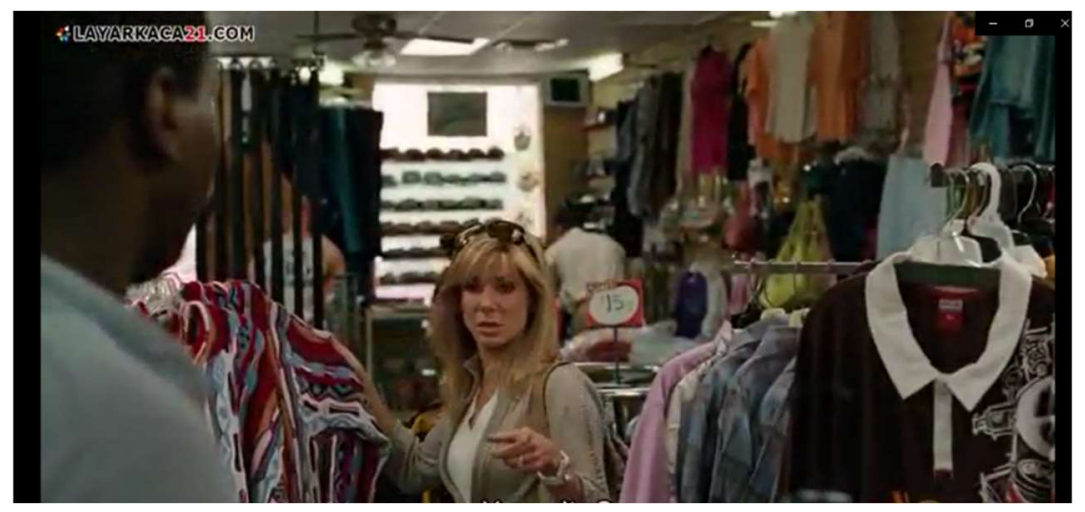

Figure 2: Leigh Anne bought clothes for Oher

Leigh Anne said, "Well, one thing I know about shopping is that if you don't love it in the store, you won't wear it". "The store is, where you like it best". "So before you choose something think of yourself wearing it and say to yourself". "Is this me?"

These texts show that Leigh Anne knows that Oher has only one clothes that he wears, and one clothes he brings everywhere in his plastic bag. Leigh Anne care about Michael, she shows him about shopping, she gives Oherwhat he needs.

3. Leigh Anne tries to look for Michael's ability and help him to get his goal of life. 


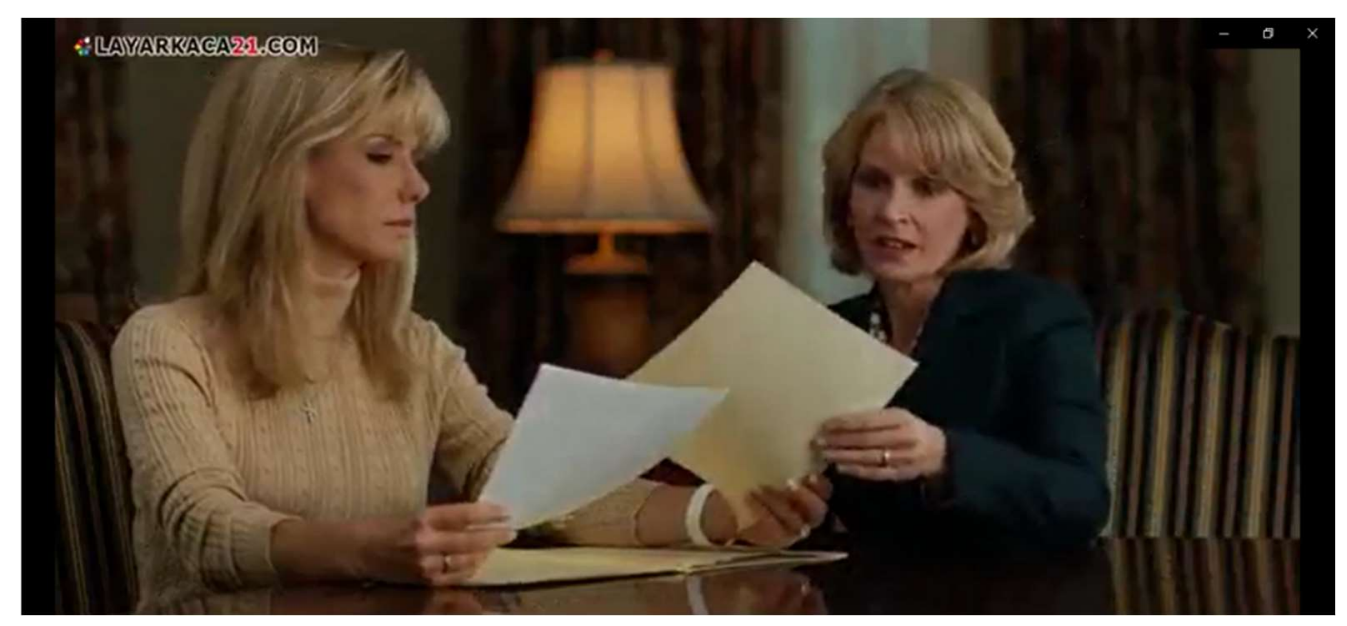

Figure 3: Leigh Anne meets Michael teacher's to look for some information about Oher's records, in the school.

The followings are their dialogues.

Teacher: "The state makes schools measure for career aptitude in eightgrade, and this just came with his file".

Leigh Anne: "What does it say about Michael?".

Teacher: "Spatial relations - third percentile". "Ability to learn - the fifth percentile". "It's funny though". "He tested in the 98th percentile in one category".

Leigh Anne: "Which one?

Teacher: "Protective instincts".

Leigh Anne: "So over here we have a desk.Chest o'drawers".

These texts are concluded that Oher has a good score in "Protective instincts", then Mrs. Leigh Anne talks to her husband, she talks to Coach Cotton and he says thatMichael's grades have improved enough that he can go out for spring footballin March.

4. All the children listen to the mom's reading story

They listen to their mom.

"Once upon a time in Spain, there was alittle bull and his name was Ferdinand". "All the other little bulls he lived withwould run and jumpand butt their heads together,but not Ferdinand". "He liked to sit just quietlyand smell the flowers". "He had a favorite spot out in the pastureunder a cork tree". "It was his favorite treeand he would sit in its shade all dayand smell the flowers".

This situation can be concluded that Mrs. Tuohy is a very kind mother. She makes her children happy. Moreover, she makes Oher happy to listen to the book story that she read. Because this is the first for Oher to listen to her mom reading the story. 


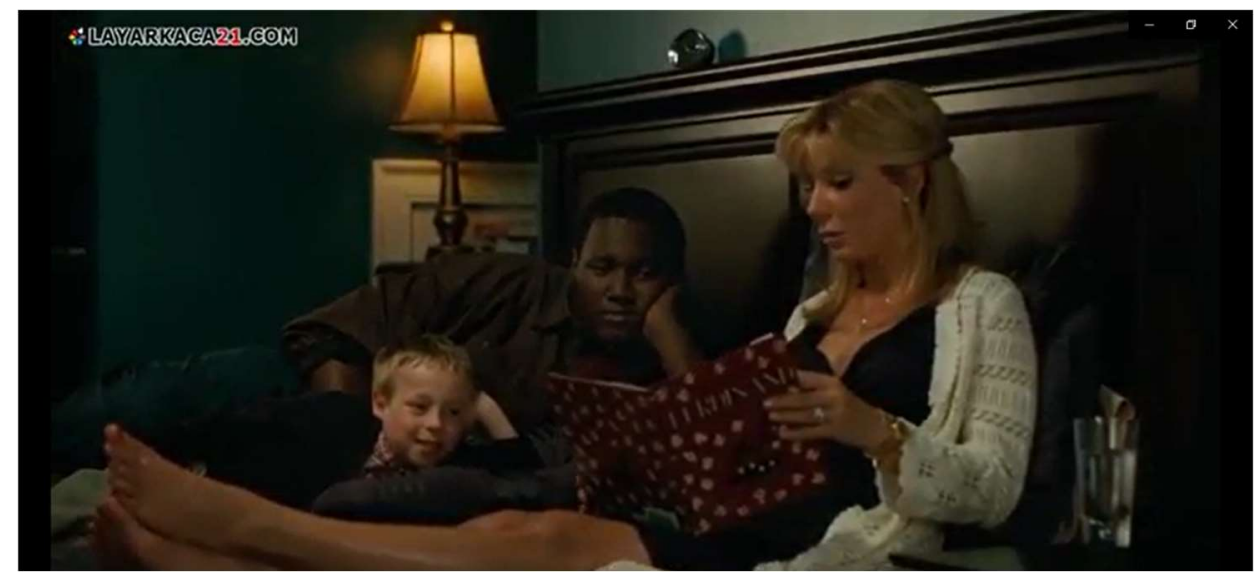

Figure 4: Leigh Anne is reading a story for her children, it is the first time for Oher feels happy listening to her mom is reading a story.

5. A Happy family take the picture for merry Christmas

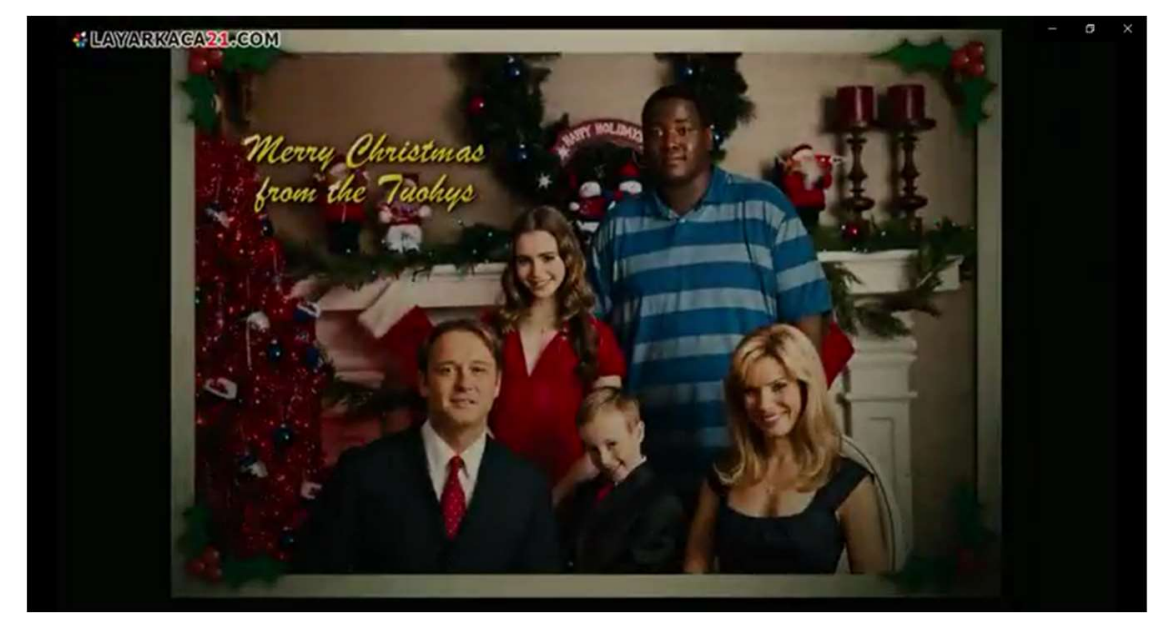

Figure 5: Tuohy's family invite Oher to take picture for merry Christmas Mr. Tuohys: "Michael! Michael comes over here", "and get in the next one".

Mrs. Tuohy: "Come on". "Come on". "Come over here”. “Oh, come on". "I'm gonna put it on the Christmas card".

Tuohys family are very kind of people, "I'm gonnaput it on the Christmas card", means that all of them are family, it shows from their daily activity that they receive Oher to be their family. Then they take the memories in the picture.

6. Leigh anna meets her friends to show her project. 


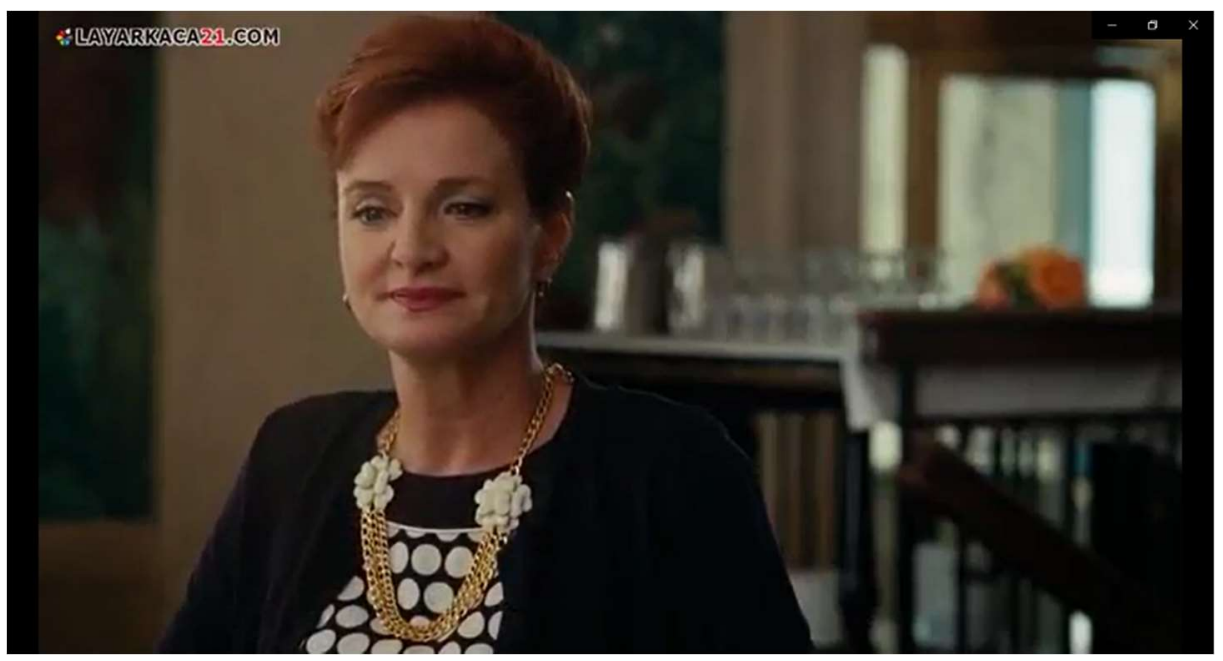

Figure 6:Leigh Anna's friend laughs at the project to help Oher.

Leigh anna: "Any of you all spent much timeon the other side of town"?

Leigh Anna friends: "Where exactly are you talking about?Alabama Street... Hurt Village". "Hurt Village - that sounds like a threat".

Leigh Anna: "You're not far off".

Leigh Anna friends: "I think it might "hurt" me to go there.It'd hurt your reputation to go there".

Leigh Anna: "Well actually I'm from therebut didn't mind hard workand look where I am now".

Leigh Anna friends: "Eating an eighteen dollar salad.And it's a little soggy, to be honest". "Leigh Anne? What is this sudden interestin the project?" "Is this another oneof your charities?" "Wait. A project for the projects". "Oh, that's catchy". "Money would raise itself". "Okay. Count me in, Leigh Anne".

These texts can be concluded that her friend thinks that what Leigh Anna is a joke. This means that they don't agree with her project to help Oher.

7. Leigh Anne wants to be Michael legal parents.

Leigh Anne: "Mrs. Oher, was Michael bornunder a different name?".

Mrs. Oher: "Proctor". "That was his Daddy's last name".

Leigh Anne: Where is he?

Mrs. Oher: "Ain't seen him since he left". "And when was that?The week after was Mike born?".

Leigh Anne: “Do you have his birth certificate?" “It's alright". “I'll figure it out.Mrs. Oher, you'll alwaysbe Michael's Mama". "Would you like to see him?".

Mrs. Oher: "No. Not this way". "It's Williams". "His last name's Williams". “Couldn't even remember who the boy's father is". 
Mrs. Oher is heavy to give information and permission about Michael Oher to Mrs. Tuohy. Because she is afraid of letting Oher go from her. But Mrs. Tuohy makes Mrs. Oher Trust her. And finally, she gives information and permission.

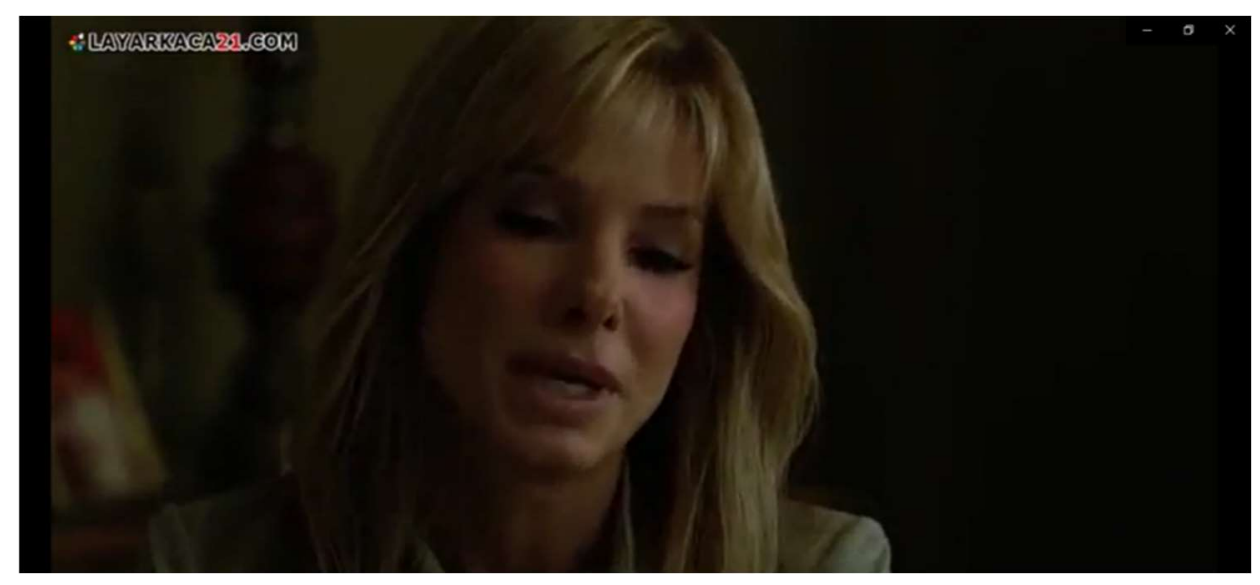

Figure 7:Leigh Anne meets Mrs. Oher to ask permission for adopting Michael Oher 8. Announce that Mr. Tuohy and his wife want to be Michael's legal guardians.

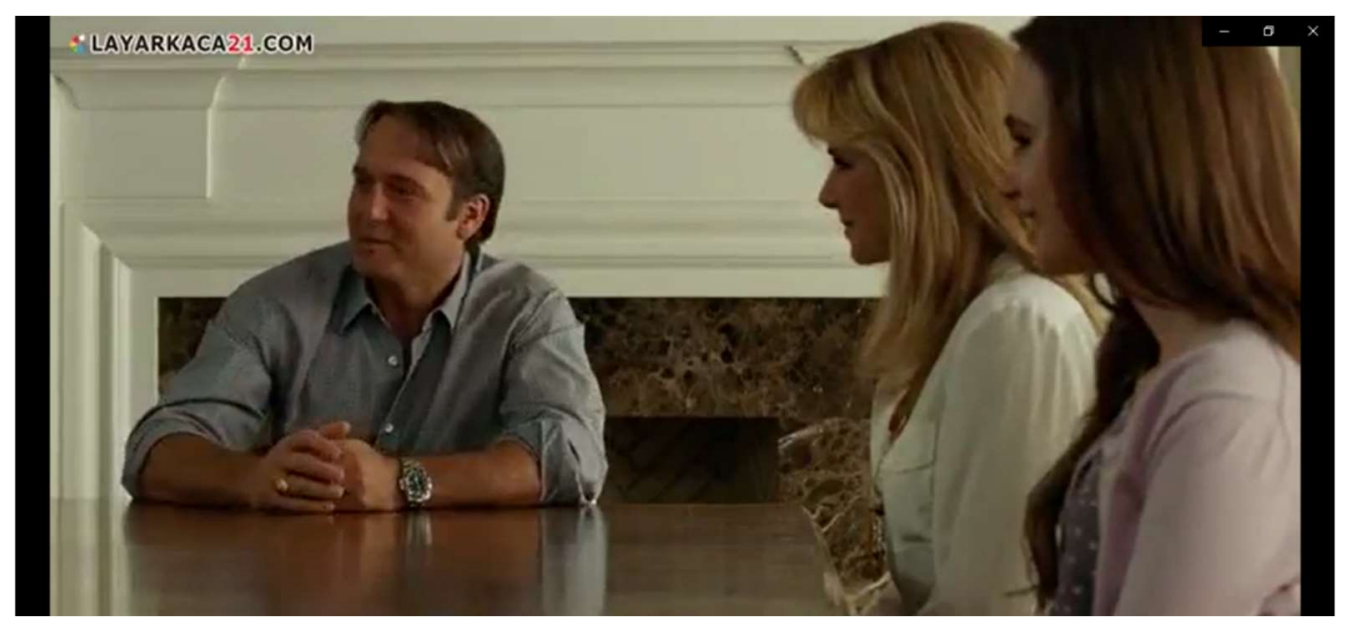

Figure 8: Mr. Tuohy and his wife said that They want to be Michael Oher's legal parents.

Mr. Tuohy: "Michael, we have somethingwe'd like to ask you".

Michael: "What?".

Mr. Tuohy: "Leigh Anne and I, we...Well...We'd like to become your legal guardians". Michael: "What's that mean?".

Mr. Tuohy: "What it means is, that we want to knowif you'd like to becomea part of thisfamily?".

Michael: "I kinda thought I already was".

Mr. Tuohy: "Well alright then".

Finally, Mr. Tuohy and his wife to be Oher's legal parents. It makes them happy. 
9. Leigh Anne knows how to guide Michael to be a good American football player.

Leigh Anne: "Michael,do you rememberwhen we first metwe went to that horrible part of townto buy those dreadful clothes? And I was a little bit scaredand you told me not to worry aboutbecause you had my back. Do you remember that?".

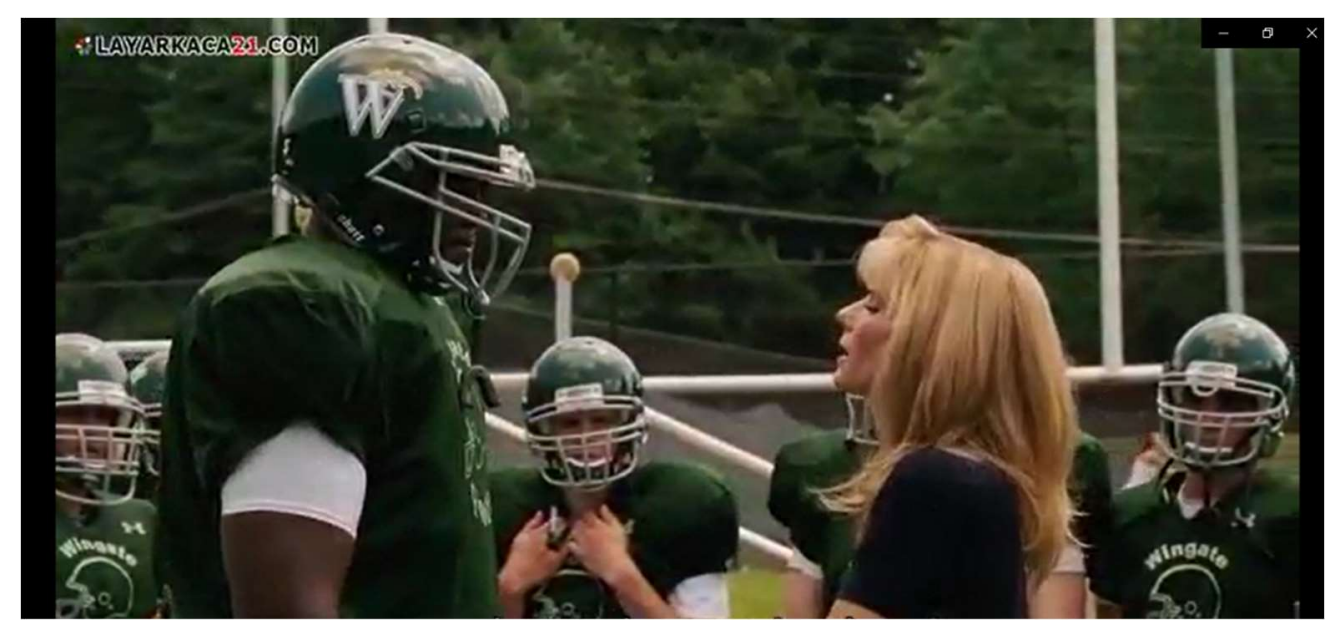

Figure 9: Leigh Anne teaches him how to do it in the American football team.

Michael: "Yes, ma'am".

Leigh Anne: "And If anyone tried to get to me,you would have stopped them, alright?And when you and SJ werein that car wreck,what did you do to that airbag?".

Michael: I stopped it.

Leigh Anne: "You stopped it". "This team is your family, Michael". "You have to protect themfrom those guys". "Okay, Listen.Okay". "Tony here is your quarterback, alright?". "You protect his blind side". "When you look at him", "you think of me". "How you had my back". "How you have his". "Okay? Alright". "Tony, go back". "Alright.here is your tailback". "When you look at him", "you think of SJ", "how you never let anyoneor anything to hurt him". "You understand meAlright". "Go back".

Mrs. Tuohy is very spirit to make Oher can play American Football. She comes to the field that Oher Practice American Football. But Oher can not play well. Then finally Mrs. Oher walks to the field to teach Oher. She explains the way to play. This is very amazing. She makes Oher Understand How to play American Football. When Oher and the team practice in the field, every people are very surprised by Mrs. Tuohy. she is successful in guiding her son to be an American Football player.

\section{Discussion}

This movie is kind of literary work, The movie was created based on the real story of Michael Lewis, This movie was directed by John Lee Han Cock. Leigh Anne succeeds to adopt, guide, support and love her stepson, his name was Michael Oher. He wasa success in American football players. Her son came from different social, and racial 
backgrounds. When Leigh Anne and Michael met for the first time, she found Michael did not have a place to stay that night. Leigh Anne saw her son has a bad experience in his life. He has an addict mother. His mother forgot who was Michael's father. He always put rump food in the gym. Then he sold the rump food.

Leigh Anne sees Oher that he didn't want to look back on his memories. Based on(Holmes, 2015)Avoidant/deactivating children tend to have parents who find it hard to tolerate their children's negative affect, leading to affect suppression; hyperactivating children's' parents are inconsistent - prompting their offspring to amplify and dwell in negative emotional states and relative helplessness, rather than transcending them, in the hope of securing parental attention.

Even he stayed in a bad social background. His environment did not influence him to be a bad son. He didn't want to hurt other people. When he wanted to play with some kindergarten students, all of them run because Michael has black people. He was very kind. He needed friends. He was always spirit going to the school even he has some bad scores. Oher's condition inspires Leigh Anne to find out a solution to Michael's problems.

Leigh Anne started to invite Oher to go shopping for some clothes for him. She gave a room to stay for Michael. It made him happy, cause he never has a room before. She read a storybook for Oher. According to (Malekpour, 2007) Healthy parent-child attachment leads to positive impacts. These positive impacts have long term effects on a child's developmental outcomes. Conversely, repeated, rejection, inconsistency in emotion and carelessness on the part of the primary caregiver towards the child are factors that lead to maladjustment in attachment development. This means that Mrs. Tuohy tied to Oher. And it made Oher feels happy to have a family. She invited Oher to take a picture together in the merriest Christmas. She meets her friend to talk about her project about Oher, but her friend was not supporting her.

The other activity of Leigh Anne, asking permission to her husband to adopt Michael, asked her daughter Collin about "whether she agreed or not to her mom project". She looked for some past activities information about Michael in order she and her husband can adopt Michael to be a legal guardian. She came to civil registration to know about Michael. Then she came to Mrs. Oher, she is Michael Oher's mother. Leigh Anne asked permission to adopt Oher.Mrs. Oher was heavy to give information and permission about Michael Oher to Mrs. Tuohy. Because she was afraid of letting Oher go from her. But Mrs. Tuohy made Mrs. Oher Trust her. Then she got the permission.

Finally, Mr. Tuohy and her wife announced that they wanted to adopt Michael Oher to be their son. Mr. Tuohy and her wife were very happy, SJ, Collin, and Michael were very happy. Mr. Tuohy and family gave Oher a new car. It means that Mrs. Tuohy and the family have tried to bring Oher, received Oher as a real family. What Mrs. Tuohy has done is in line with the attachment theory. 
A mother caring for young children has a strong desire to be cared for and supported herself. The activation of attachment behavior in these circumstances is probably universal and must be considered the norm (Bowlby, 1988). The writer concluded that Mrs. Tuohy and the family hasshown their love for Oher. By adopting him, giving a room, giving a chance to have a picture in merry Christmas, giving a car. Give him something that Oher did not have before. Maybe Oher thought that was like in the Dream. But Mrs.Tuohy made it reality happen.

Mrs. Tuohy next activity looked for some information about Oher's ability at school. Oher less on all subjects in the school. But there was one good score which was ability in "Protective instincts", Then she and her husband motivated Oher to be an American football player. This was a big support from a mother. As a mother, of course, she wanted Oher to find his goal of life. So what has Mrs. Tuohy done to educate him with love? That is a guide, Oher, to be an American football player. According to (Ainsworth, 1967) attachment is more than overt behavior, it is internal, "being built into the nervous system, in the course and as a result of the infant's experience of his transactions with the mother". In this activity, Mrs. Tuohy did not only support him in practicing football players but also guided him to be a good player. How the way played with their friend practically done by Mrs. Tuohy. She made Oher get experience and had a transaction with his mother. Finally, he understood how to play American football. His team often to be a winner. Oher also had an opportunity to get a scholarship at university.

The journal is very beneficial for everyone who reads. The benefit of this study is for other people who want to know how mother love and guide her son can change Oher's lives from a bad condition into a better life. Finally, Michael Oher and Mrs. Tuohy become a family. Their family support and love each other. They live Happily.

\section{Conclusions}

Based on the above analysis, it can be concluded as follows. Firstlythe problem faced by Mrs. Tuohy in processing adopted Oher, her friends did not agree with her project, They did not want to support Mrs. Tuohy. Secondly, When she met Oher's mom or Mrs. Oher, she asked permission to adopt Oher, but Mrs. Oher was afraid if Oher would not want to meet her mom again because He had a new mother. Then Mrs. Tuohy could convince to Oher's mom. Finally, she permitted Mrs. Tuohy for adopting Oher.

Thirdly the problem, Mrs. Tuohy looked for some information about Oher's ability at school. Then she found his good ability. She made a plan with her husband to guide Oher to be an American football player. Look for a couch for practicing American football players. She always checked Oher whether he increases his ability in playing football or not. Because Oher was difficult to understand how to play football. Mrs. Tuohy also came to the field for guiding to play football. 
She makes Oher Understand How to play American Football. When Oher and the team practice in the field, every people were very surprised with Mrs. Tuohy done. Her efforts were successful on process guiding her son to be an American Football player.All Mrs. Tuohy has done was guiding an adoption forchildren to be a successful man. This called the power of love a marvelous mother. At the end of the day, they can live happily.

\section{References}

http://www.script-o-rama.com/movie_scripts/b/the-blind-side-script-transcript.html

https://internasional.kompas.com/read/2009/04/03/09082779/Madonna.dan.Tren.Adopsi.Anak.A frika?page $=$ all

Ainsworth, M. D. S., \& Bowlby, J. (1991). An ethological approach to personality development. In American Psychologist.

Ainsworth, S. M. D. (1967). Infancy in Uganda: Infant Care and the Growth of Attachment. Baltimore, Md: The Johns Hopkins Press.

Bethmann, D., \& Kvasnicka, M. (2012). A Theory of Child Adoption. IZA Discussion Paper, (6689).

Bineham, J. L. (2015). How The Blind Side Blinds Us: Postracism and the American Dream. Southern Communication Journal, 80(3), 230-245. https://doi.org/10.1080/1041794X.2015.1030084

Bowlby, J. (1988). A SECURE BASE Parent-Child Attachment and Healthy Human Development. London: Routledge.

Brien, K. M. O., \& Wiley, M. O. L. (2003). The Practice of Adoption: History, Trends, and Social Context The Practice of Adoption. The Counseling Psychologist, (November). https://doi.org/10.1177/0011000003258061

Cutas, D., \&Smajdor, A. (2017). The moral status of the ( nuclear ) family. 11, 5-15.

Haqiqi and Harendika, M. S. (2019). American Values in John Lee Hancock's The Blind Side. Language Circle: Journal of Language and Literature, 13(2). https://doi.org/10.15294/lc.v13i2.18966

Holmes, J. (2015). Attachment T heory In Clinical Practice : A Personal Account. British Journal of Psychotherapy, 2, 208-228. https://doi.org/10.1111/bjp.12151

Kennedy, J. H. (2004). Attachment theory: Implications for school psychology. Psychology in the Schools, 4(2). https://doi.org/10.1002/pits.10153

Madonna dan TrenAdopsi Anak Afrika. (2009, April 3). Kompas.com. Retrieved from

Malekpour, M. (2007). Effect of Attachment On Early And Later Development. The British Journal of Developmental Disabilities, 53(2), 81-95. 